\title{
EDUCAÇÃO E CRISE: PERSPECTIVAS PARA O BRASIL
}

\author{
Carlos Roberto Jamil Cury*
}

\begin{abstract}
RESUMO: A atual crise internacional tem suscitado a retomada do papel do Estado e o questionamento da supremacia do mercado e seus agentes. Esta crise confirma o foco de algumas iniciativas legais e de alguns programas governamentais federais em favor da educação escolar pública no Brasil. $\mathrm{O}$ artigo lista a maior parte dessas leis, objetivando mostrar que elas, junto com os programas, se inclinam no sentido de uma presença maior do Estado no âmbito do direito à educação.
\end{abstract}

Palavras-chave: Estado e educação. Educação, Estado e direito à educação. Políticas de educação. Direito à educação.

\section{EDUCATION AND CRISIS: PERSPECTIVES FOR BRAZIL}

ABSTRACT: The present international crisis suggests that the State springs back to its role and questions the supremacy of the market and its agents. It confirms the focus of some legal actions and government programs in the sake of public education in Brazil. This paper lists most laws on education to show that, together with the programs, they tend toward a larger presence of the State in the field of the right to education.

Key words: State and education. Education, State and the right to education. Education policies. Right to education.

Doutor em Educação e professor do Departamento de Educação da Pontifícia Universidade Católica de Minas Gerais (PUC-MG).E-mail: crjcury.bh@terra.com.br 


\section{$\mathcal{A}$}

área da educação, por qualquer ângulo que se veja, é sempre crítica. Crítica no sentido de quem julga ou examina um assunto com acuidade, distinguindo e analisando os componentes desse assunto. Mas é crítica também no sentido de estar em uma situação difícil e embaraçosa. No primeiro sentido, ela é uma área ativa, que faz, que produz. Muitas vezes, esse sentido se recobre de uma dimensão cortante como um machado, que corta a lenha para ver sua anatomia, sua estrutura e apontar o quê fazer. No segundo sentido, ela padece de uma situação carregada de limitações, de insuficiências dentro de um quadro severo, cujas condiçōes graves e preocupantes são perceptíveis. Muitas vezes, esse sentido se recobre de uma dimensão paralisante como um beco sem saída.

A história de nossa educação cruza, o tempo todo, essas duas dimensões em que situação severa e insatisfação pela permanência da mesma situação impôs ora um discurso da educação redentora dos males, ora reprodutora da dominação de classe, ora um pilar necessário, conquanto não suficiente em vista de uma saída. Situação, análise e doutrina envolveram discursos desde o ser assim até os meandros do dever ser. Doutrinas do dever ser se antepuseram como elementos apriorísticos ou dogmáticos, tanto quanto a insistência nos resultados se isolou em dimensões pragmatistas e conjunturais.

Da parte dos intelectuais da educação, para os quais um direito como a educação não é o mesmo que um objeto com seu valor de troca, o interesse pela situação, pela sua radiografia, pela sua anatomia, pelo conhecimento de seus mecanismos caminha no sentido de neles ver se os mesmos contêm, no seu sendo, uma capacidade de serem portas ou janelas para um ainda-não, mas já aí, ou seja, de um futuro de mudança inovadora e mais abrangente para todos.

Convivendo com a crise, crise que é o DNA da educação em um e outro sentido, passando por todas suas variantes, a revista Educação \& Sociedade se impôs nesses 30 anos como um observatório (crítico) da educação nacional sem dogmatismos, sem sectarismos. Ao mesmo tempo, sabedora da educação como direito social saído de uma necessidade coletiva, no interior de uma sociedade desigual, de um país díspar no qual ainda viceja a discriminação, sem subalternidade, coloca como seu princípio o sentido maior de público, tendo entre os esteios do mesmo uma sociedade civil organizada e um Estado democrático, em vista do lado emancipatório e democrático que a educação carrega consigo. 
A crise, cujo título é o tema desta mesa e para cuja realidade parece apontar, é tanto aquela que, ano passado, atingiu o sistema financeiro mundial quanto, como decorrência da mesma, o desfecho da celebração do mercado como único referente da vida social. Este desfecho, que põe por terra o pensamento único, o fim da História, a satanização do Estado, abre um espaço de reflexão importante a que conduz toda situação crítica. A crise tem permitido questionar se é mesmo inerente ao capitalismo carrear todos os recursos para o capital financeiro, acuar os direitos sociais e retirar do Estado o seu espaço de regulação e de intervenção. E ela tem permitido questionar, ainda com mais força, a decantada racionalidade da autorregulação do e pelo mercado e se tal dinâmica pode satisfazer a todos os termos do crescimento autossustentado e do desenvolvimento equânime. E, finalmente, ela tem permitido uma retomada da discussão sobre as pressões pelos direitos sociais e pelo papel do Estado. Isso não significa nem o arrefecimento do capitalismo, cuja capacidade de adequação é elástica, nem o fim de todo o neoliberalismo, mas tem significado a retomada da discussão do que significa o espaço público e de quais são os limites do espaço privado.

Ora, o governo que hoje existe no país, sem tocar de modo efetivo no processo de redistribuição da renda, vem, desde o seu início, tomando posições em favor de uma transferência da renda por meio de bolsas, de facilitação e ampliação do crédito e de incentivos em campos mais produtivos como o da construção civil. Isso não significa uma queda na desigualdade tão característica de nosso país, mas também não se pode fechar os olhos para outras ações que vêm sendo tomadas pelo governo, inclusive no campo da educação.

Evidentemente sujeita à uma verificação mais detalhada, parto de uma hipótese que, no campo da educação escolar, o atual governo se destaca pela expansão de sua rede pública própria (a federal) e, ao mesmo tempo, não inibe significativamente a rede privada superior que lhe está afeita. Ao mesmo tempo, o atual governo tem tido uma presença mais efetiva na modelação dos sistemas de ensino, ensejando um papel mais ativo do governo da União. Outra presença mais efetiva da União vem se impondo no âmbito do direito à diferença.

No âmbito do ensino superior, deve-se apontar a Lei n. 10.861, de abril de 2004, que instituiu o Sistema Nacional de Avaliação da Educação Superior (SINAES) que alterou a metodologia de avaliação 
estabelecida pelo denominado "Provão" ou Exame Nacional de Cursos. Dentre outros avanços, destacam-se o Exame Nacional de Desempenho do Estudante (ENADE), a Comissão Própria de Avaliação (CPA) e o Termo de Compromisso, quando identificadas insuficiências da parte de instituições avaliadas.

A Lei n. 11.091, de 2005, instituiu o Plano de Cargos e Salários dos técnico-administrativos da rede pública federal de ensino superior. Paralelamente, o sistema privado se viu recompensado com a Lei n. 11.096/05, que criou o Programa Universidade para Todos (PROUNI). De um lado, tal lei exige a contrapartida das IEs que gozam do benefício posto no artigo 150, VI, letra c, da Constituição. De outro, a ampliação para todas as IES privadas parece conflitar com o $\$ 2^{\circ}$ do inciso II, do artigo 213 da mesma Constituição.

Campo ainda em aberto e que parece ter sido tirado de qualquer urgência é o Projeto de Lei n. 7.200, de 2004. Trata-se de um projeto, de feição nitidamente embrionária (versão preliminar), anteprojeto de lei do qual se sabe como entra no Congresso Nacional, mas certamente não se sabe como sai(rá). O anteprojeto sinaliza a procura de um marco regulatório para a iniciativa privada na educação superior e busca um caminho de recomposição da universidade pública federal após a omissão do Governo FHC e o esquecimento do primeiro Ministério da Educação no Governo Lula. A impressão que fica, apesar da boa vontade em querer acertar, é que o anteprojeto não sabe como enfrentar a verdade dos fatos da iniciativa privada e a situação preocupante do sistema público e nem como se confrontar com a LDB. Parece que o anteprojeto gostaria de revogar a LDB e, como não explicita isso e como o encaminhamento tem que ser pelas vias jurídico-parlamentares, acaba por embrenhar-se por caminhos pouco claros e nem sempre lógicos e convincentes. Eis porque, diante do novo Exame Nacional do Ensino Médio (ENEM) como forma de ingresso às universidades, da responsabilização da União pela formação de professores da educação básica, da criação do Programa de Apoio a Planos de Reestruturação e Expansão das Universidades Federais (REUNI) e da interiorização das instituições públicas de ensino superior, podese dizer que tais iniciativas pretendem suprir caso a caso, o que poderia se articular organicamente em uma LDB emendada.

Lei n. 11.502/07 - Modifica as competências e a estrutura organizacional da fundação Coordenação de Aperfeiçoamento de Pessoal de 
Nível Superior (CAPES), de que trata a Lei n. 8.405, de 9 de janeiro de 1992; e altera as Leis n. 8.405, de 9 de janeiro de 1992, e n. 11.273, de 6 de fevereiro de 2006, que autoriza a concessão de bolsas de estudo e de pesquisa a participantes de programas de formação inicial e continuada de professores para a educação básica.

\section{Expansão da rede federal de ensino superior ${ }^{1}$}

No período, as instituições federais de educação profissional, de acordo com o Instituto Nacional de Estudos e Pesquisas Educacionais Anísio Teixeira (inep), desde 2003, cresceram em 173 unidades das 214 unidades planejadas. Isso significa um crescimento de $123 \%$ em relação às 140 escolas de educação profissional que foram criadas entre $1909 \mathrm{e}$ 2002. Tal expansão se deu em todos os estados da União e com vetor de interiorização. Hoje: Bahia (25), Rio de Janeiro (14), Minas Gerais/São Paulo (24), Rio Grande do Sul (23), Goiás (13), Ceará/Piauí/Rio Grande do Norte (11), Mato Grosso (10), Paraíba (9), Alagoas (8), Paranál Mato Grosso do Sul (7), Santa Catarina (19), Sergipe/Tocantins (6), Maranhão (18), Rondônia/Distrito Federal (5), Espírito Santo (14), Roraima/Acre (3), Pernambuco (14), Amapá (2).

Houve também um crescimento quanto às universidades federais. Em 1999, eram 39 e hoje são 55. Foram criados 16 CEFETs, 11 Universidades Tecnológicas e 23 IFETs.

Pelo Decreto n. 6.096/07 foi criado o REUNI que, com base no atual Plano Nacional de Educação, visa à ampliação financiada de vagas na graduação, especialmente no noturno. O Decreto n. 5.622/ 06 regulamentou o artigo 80 da LDB, normatizando a educação a distância, em cujas bases houve a instituição do Sistema Universidade Aberta do Brasil (UAB) e que tem como principal objetivo expandir a oferta de cursos e programas de educação superior por meio de sua interiorização.

Outro ponto de interesse especial é o da formação de professores. A Lei n. 11.502/07, modificando a estrutura e as competências da CAPES, trouxe para esta a tarefa de induzir e fomentar convênios com os entes federativos voltados para a formação inicial e continuada de profissionais do magistério. Deriva dessa lei tanto a constituição de um Conselho Técnico-Consultivo da Educação Básica quanto 
o Decreto n. 6.755/09, que institui a Política Nacional de Formação do Magistério da Educação Básica e do qual resulta o Plano Nacional de Formação dos Professores da Educação Básica, e tudo isso se articula com a mudança do artigo 62 da LDB pela Lei n. 12.056/09.

No âmbito da educação básica

1) Emenda Constitucional n. 53/06 - FUNDEB é regulamentado pela Lei n. 11.738/08

Emenda Constitucional n. 59/09 - término progressivo da (DRU), ampliação da faixa etária da educação obrigatória, alterando a mesma de 6 a 14 anos para de 4 a 17 anos, assegurada sua oferta gratuita para todos os que a ela não tiveram acesso na idade própria. E o artigo 214 (emendado) traz um elemento muito diferenciado e com novidades: "A lei estabelecerá o Plano Nacional de Educação, de duração decenal, com o objetivo de articular o sistema nacional de educação em regime de colaboração. (...) que conduzam a: (...) VI - estabelecimento de meta de aplicação de recursos públicos em educação como proporção do produto interno bruto".

2) Leis ordinárias: no Governo Lula (2003-2009), até agora foram 24 alteraçôes na $L D B^{2}$

Lei n. 10.639/03 - artigos 26-A, 79-A e 79-B - História e cultura afro-brasileira.

Lei n. 10.709/03 - artigos 10 e 11 - Transporte escolar.

Lei n. 10.793/03 - artigo 26 - Educação física.

Lei n. $11.114 / 05$ - artigos $6^{\circ}, 30,32,87$ - entrada no ensino fundamental aos 6 anos de idade.

Lei n. 11.183 - artigo 20 - Escolas comunitárias e cooperadas.

Lei n. 11.274/06 - artigos 29, 30, 32 e 87 - escolaridade obrigatória desde os 6 anos até os 14 anos.

Lei n. 11.301/06 - artigo 67 - Define funções do magistério.

Lei n. 11.330/06 - artigo 87 - amplia deveres dos estados. 
Lei n. 11.331/06 - artigo 44 - Processo seletivo e ensino superior, transferências.

Lei n. 11.525/07 - artigo 32 - ECA no ensino fundamental.

Lei n. 11.632/07 - artigo 44, I - Cursos sequenciais.

Lei n. 11.645 - artigos 26-A, 79-A e 79-B - História e cultura afro-brasileira e indígena.

Lei n. 11.684/08 - artigo 36 - Filosofia e Sociologia no ensino médio.

Lei n. 11.700/08 - artigo $4^{\circ}$ - Vaga de educação infantil e ensino fundamental em escola pública desde os 4 anos.

Lei n. 11.741/08 - artigos 37, 39, 41 e 42 - Educação profissional.

Lei n. 11.769/08 - artigo 26 - Ensino de música.

Lei n. 11.788/08 - artigo 82 - Estágio.

Lei n. 11.988/09 - Ensino fundamental e Semana da Educação para a Vida.

Lei n. 12.013/09 - artigo 12 - Pais, tutores e responsáveis pela frequência.

Lei n. 12.014/09 - artigo 61 - Quem são os profissionais da Educação.

Lei n. 12.020/09 - artigo 20 - Escolas comunitárias e cooperativas educacionais.

Lei n. 12.056/09 - artigo 62 - a União na formação docente.

Lei n. 12.061/09 - artigos $4^{\circ}$ e 10 - Universalização do ensino médio gratuito sob demanda dos indivíduos.

3) Leis correlatas

Lei n. 10.880/04 - PNATE/EJA.

Lei n. 11.161/05 - Ensino do espanhol no ensino médio

Lei n. 10.836/04 - Bolsa-família.

Lei n. 12.031/09 - Execução semanal do Hino Nacional. 
4) Decretos

Decreto n. 5.154/04 - artigos 36, 39-41 - Educação profissional.

Decreto n. 5.622/05 - artigo 80 da LDB - EaD.

Decreto n. 6.253/07 - FUNDEB/Lei n. 11.494/07.

Decreto n. 6.571/08 - artigo $60 \$$ único da LDB - Necessidades especiais.

Decreto n. 6.861/09 - Educação indígena e territórios etnoeducacionais.

5) Portaria Normativa n. 09/09 - Plano Nacional de Formação dos Professores da Educação Básica no âmbito do MEC

6) Resolução CNE/CEB n. 02/09 - Diretrizes dos Planos de Carreira do Pessoal Docente

Em elaboração: Parecer do Conselho Nacional de Educação sobre o custo aluno-qualidade (CAQ) - exigência posta tanto na LDB quanto no FUNDEB.

7) Temáticas e alteraçôes

Currículo e diferença: 6 leis +2 decretos.

MDE: 1 lei.

Faixa etária: 4 leis.

Administração: 2 leis.

Magistério: 2 leis.

Federalismo: 2 leis.

Processo seletivo: 1 lei.

Cursos sequenciais: 1 lei.

Educação profissional: 1 lei,

Estágio: 1 lei.

$\mathrm{EaD}-1$ decreto. 


\section{Considerações finais}

No âmbito do ensino superior, o que se nota claramente é uma política de expansão das instituições públicas, seja pela via da educação presencial, seja pela via da educação a distância. Em ambos os casos, o aparato jurídico contempla a sua interiorização. Após um crescimento exponencial do segmento privado, ele parece ter atingido o seu teto. A lei do SINAES, que impóe critérios de atuação e avaliação, dada a sua complexidade, tem ainda um movimento muito lento. A reforma universitária não tem mais o sentido de urgência da parte do governo.

No âmbito da ligação entre o ensino superior e a educação básica, o que se nota é a entrada mais explícita da União no circuito da formação de professores, especialmente pela via da CAPES, por meio da instituição do Conselho Técnico-Científico da Educação Básica (СТC/EB).

$\mathrm{Na}$ educação básica, a atuação tem sido em prol da ampliação da obrigatoriedade da educação infantil e do ensino médio, da integração entre ensino médio e educação profissional, e da busca de explicitação do regime de colaboração.

Finalmente, o Estado se viu compelido, seja pelo atual Plano Nacional de Educação, seja por estar buscando um melhor desempenho da avaliação da educação nacional, à realização da Conferência Nacional de Educação (CONAE).

Tais realidades indicam ou postulam uma presença maior do Estado, que recusa o Estado mínimo, mas que também não chega a ser um Estado predominantemente interventor. Certamente, os avanços obtidos são ainda insuficientes para dar conta das realidades a serem superadas e são incapazes de retirar da comunidade científica um grau de insatisfação face às promessas e expectativas postas no atual governo federal. A educação como direito social, como bem público e, no âmbito dos poderes governamentais, como um serviço público, não pode e nem deve ficar ao sabor do mercado, como se fosse uma mercadoria. A Constituição, em seu artigo $208, \$ 2^{\circ}$, já impõe responsabilidade a quem assume um poder de Estado e, por ser assim, assume que a educação é dever porque é direito. O gestor público se compromete claramente com a vinculação substantiva e jurídica entre o objetivo (dever do Estado) e o subjetivo (direito da pessoa). A Lei n. 9.394/96, a de diretrizes e bases da educação nacional, explicita, no $\$ 3^{\circ}$ do artigo $5^{\circ}$, 
que qualquer indivíduo que se sentir lesionado neste direito pode dirigir-se ao Poder Judiciário para efeito de reparação, sendo tal ação gratuita e de rito sumário. A Lei n. 1.079/50 define os crimes de responsabilidade. $\mathrm{O}$ artigo $4^{\circ}$ desta lei define como crime de responsabilidade aquele em que a autoridade venha a atentar contra o exercício dos direitos politicos, individuais e sociais.

É preciso, pois, uma articulação entre esses dispositivos, que os reúna, que os normatize e que dê a devida publicidade a uns e a consciência a outros. Tal é a base para uma Lei de Responsabilidade Educacional. O artigo 37 da Constituição, pelas características e natureza do poder público, implica que os governantes assumam conscientemente suas responsabilidades. E no caso de não cumpri-las, deve haver consequências, como o de imputação de improbidade administrativa.

Tal lei permite dar consequência ao Plano Nacional de Educação realista em suas metas, que, por sua vez, decorrerá de um sistema nacional de educação, articulado, democrático e federativo.

Recebido em fevereiro de 2010 e aprovado em março de 2010.

\section{Notas}

1. Lei n. 11.096/05, que institui o ProunI.

2. No Governo FHC, houve quatro alteraçôes na LDB: Lei n. 9475/97 do artigo 33 (ER); n. 9.536/97 do artigo 49 (ex officio), n. 10.287/01 do artigo 12 sobre faltas e Conselho Tutelar; n. 10.328/01 do artigo 26 sobre Educação Física. 